\title{
Regulation of intracellular pH during oocyte growth and maturation in mammals
}

\author{
Greg FitzHarris and Jay M Baltz ${ }^{1}$ \\ Institute for Women's Health, University College London, 86-96 Chenies Mews, London WC1E 6HX, UK and ${ }^{1}$ Ottawa \\ Health Research Institute and Departments of Obstetrics and Gynecology (Division of Reproductive Medicine) and \\ Cellular and Molecular Medicine, University of Ottawa, Ottawa, Ontario K1Y 4E9, Canada
}

Correspondence should be addressed to G FitzHarris; Email: g.fitzharris@ucl.ac.uk

J M Baltz; Email: jmbaltz@ohri.ca

\begin{abstract}
Regulation of intracellular $\mathrm{pH}\left(\mathrm{pH}_{\mathrm{i}}\right)$ is a fundamental homeostatic process essential for the survival and proliferation of virtually all cell types. The mammalian preimplantation embryo, for example, possesses $\mathrm{Na}^{+} / \mathrm{H}^{+}$and $\mathrm{HCO}_{3}^{-} / \mathrm{Cl}^{-}$exchangers that robustly regulate against acidosis and alkalosis respectively. Inhibition of these transporters prevents $\mathrm{pH}$ corrections and, perhaps unsurprisingly, leads to impaired embryogenesis. However, recent studies have revealed that the role and regulation of $\mathrm{pH}_{\mathrm{i}}$ is somewhat more complex in the case of the developing and maturing oocyte. Small meiotically incompetent growing oocytes are apparently incapable of regulating their own $\mathrm{pH}_{\mathrm{i}}$, and instead rely upon the surrounding granulosa cells to correct ooplasmic $\mathrm{pH}$, until such a time that the oocyte has developed the capacity to regulate its own $\mathrm{pH}_{\mathrm{i}}$. Later, during meiotic maturation, $\mathrm{pH}_{\mathrm{i}}$-regulating activities that were developed during growth are inactivated, apparently under the control of MAPK signalling, until the oocyte is successfully fertilized. Here, we will discuss pH homeostasis in early mammalian development, focussing on recent developments highlighting the unusual and unexpected scenario of $\mathrm{pH}$ regulation during oocyte growth and maturation.

Reproduction (2009) 138 619-627
\end{abstract}

\section{Introduction: growth and maturation of the mammalian oocyte}

Mammalian oocytes grow within ovarian follicles, each comprising a single oocyte enclosed within a surrounding shell of granulosa cells. For every reproductive cycle, a group of primordial follicles, consisting of a small nongrowing primordial oocyte and a single layer of granulosa cells, is selected to begin growing. The oocyte increases in size from $\sim 20 \mu \mathrm{m}$ in diameter to a speciesdependent final size of $70-120 \mu \mathrm{m}$, with fully grown oocytes of the most common experimental model, the mouse, reaching about $75 \mu \mathrm{m}$ by the end of the growth phase. Oocyte growth is an indispensable component of oogenesis, since in the mouse oocytes only become capable of resuming meiosis when they reach about $80 \%$ of their final size (Sorensen \& Wassarman 1976, Wassarman et al. 1979). Oocyte growth is also absolutely dependent upon the presence of, and communication with, the surrounding granulosa cells (Eppig 1985, 1991, Buccione et al. 1990, Su et al. 2009). Granulosa cells are coupled to the enclosed oocyte via gap junctions that, at least in mouse, are composed principally of connexin 37 (Cx37) subunits (Simon et al. 1997, Kidder \& Mhawi 2002). During growth, the granulosa cells proliferate rapidly, such that the follicle expands, and eventually forms a fluid-filled antrum from which the fully grown oocyte, surrounded by cumulus granulosa cells, is ovulated.

Throughout the growth phase, the oocyte is arrested in first meiotic prophase with a prominent prophase nucleus, termed the germinal vesicle (GV). The LH surge serves as the trigger for ovulation, and is also the signal for the oocyte to resume meiosis. The GV breaks down and the oocyte completes the first meiotic division $(\mathrm{MI})$, ending in an unequal cell division forming a tiny nonviable first polar body (Pb1) and a large oocyte. The oocyte immediately enters the second meiotic division (MII), but arrests in metaphase until successfully fertilized (termed the MII arrest). It is around this time that the oocyte is expelled from the follicle and begins its journey along the oviduct (fallopian tube), and granulosa cells secrete hyaluronic acid matrix causing them to be physically uncoupled from the oocyte, including loss of gap junctional communication (Eppig 1982). Successful fertilization in the ampulla of the oviduct initiates a cascade of events culminating in the resumption of meiosis, extrusion of the $\mathrm{Pb} 2$, and initiation of embryonic division. The cleaving embryo differentiates into a blastocyst some 5 days after ovulation (in mouse), 
around which time the successful embryo attaches to the uterus marking the end of preimplantation (PI) development. Thus, having remained arrested from birth until it is recruited to grow at some point after puberty, the oocyte is transformed from a tiny primordial oocyte within the ovary to a partially differentiated embryo in a matter of a few weeks (see Fig. 1).

Given the changes in the physiological demands and external environment, it seems logical that the oocyte and early embryo should be equipped to adapt to its changing circumstances. Here, we review what we know about one major aspect of oocyte/embryo homeostasis - regulation of intracellular $\mathrm{pH}\left(\mathrm{pH}_{\mathrm{i}}\right)$. We approach the question in 'reverse' order. First, we will briefly review the relatively intuitive scenario of $\mathrm{PI}$ embryo development. Then we focus on recent work that has revealed the mechanisms and control of $\mathrm{pH}$ regulation in the growing and maturing oocyte to be far less obvious.

\section{Cellular homeostasis: the $\mathrm{pH}$ regulation toolkit}

Virtually all cells possess the ability to regulate against unwelcome perturbations in $\mathrm{pH}_{\mathrm{i}}$. Most cellular processes are acutely $\mathrm{pH}$ sensitive, and so it is unsurprising that impairment of $\mathrm{pH}_{\mathrm{i}}$ regulation can critically compromise cell function and viability. Classic experiments in cultured somatic cells showed that growth and proliferation are impaired if $\mathrm{pH}_{\mathrm{i}}$ regulation is compromised and $\mathrm{pH}_{\mathrm{i}}$ is disturbed (Grinstein et al. 1989, Kapus et al. 1994), and $\mathrm{pH}_{\mathrm{i}}$ dysregulation has been shown to jeopardize cell survival (Pouyssegur et al. 1984). The mammalian cell has therefore been equipped to maintain a normal $\mathrm{pH}_{\mathrm{i}}$ in response to changing environments and metabolic acid generation. To correct alkalosis, most mammalian cells possess $\mathrm{HCO}_{3}^{-} / \mathrm{Cl}^{-}$ exchangers of the anion exchange $(\mathrm{AE})$ family $(\mathrm{AE}$ - three isoforms with various splice variants), which export $\mathrm{HCO}_{3}^{-}$in exchange for $\mathrm{Cl}^{-}$, thereby raising $\mathrm{pH}_{\mathrm{i}}$ (Alper
1991, Romero et al. 2004). The principal means for correcting acidosis are $\mathrm{Na}^{+} / \mathrm{H}^{+}$exchangers (NHEs) of the NHE gene family, which export protons in exchange for $\mathrm{Na}^{+}$, thereby raising $\mathrm{pH}_{\mathrm{i}}$ (Orlowski \& Grinstein 2004). Out of the nine known NHE isoforms, five (NHE1-5) are known to reside at least partly in the plasmalemma, and may therefore regulate $\mathrm{pH}_{\mathrm{i}}($ Orlowski \& Grinstein 2004, Romero et al. 2004). Dependent upon the cell type, these two main players may be backed by a supporting cast including $\mathrm{Na}^{+}, \mathrm{HCO}_{3}^{-} / \mathrm{Cl}^{-}$exchangers (NBC) that relieve acidosis in some cell types by importing $\mathrm{HCO}_{3}^{-}$(Romero et al. 2004), and V-type $\mathrm{H}^{+}$-ATPases (V-ATPases) that export protons across the plasmalemma in some cells (Merzendorfer et al. 1997, Nelson \& Harvey 1999, Kawasaki-Nishi et al. 2003). The study of cellular $\mathrm{pH}_{\mathrm{i}}$ regulation has been facilitated considerably by commercially available $\mathrm{pH}$-sensitive fluorophores, such as BCECF and SNARF, which allow $\mathrm{pH}_{\mathrm{i}}$ measurement during experimental manipulations in living cells. For example, real-time recording of the recovery of a cell from an induced acidosis or alkalosis can be performed, and identification of the transport systems responsible for the recovery can be achieved by inhibition of each system.

\section{Role of pH in early embryo development}

It is well established that $\mathrm{pH}_{\mathrm{i}}$ regulation is of importance in early mammalian development. The PI mouse embryo has very active $\mathrm{HCO}_{3}^{-} / \mathrm{Cl}^{-}$exchange for mitigating alkalosis (Baltz et al. 1991, Zhao et al. 1995, Zhao \& Baltz 1996, Phillips \& Baltz 1999), which is also seen in human (Dale et al. 1998, Phillips et al. 2000), hamster (Lane et al. 1999a), and, to a lesser extent, bovine embryos (Lane \& Bavister 1999). The effectiveness of these exchangers is substantial; one-cell mouse embryos can efficiently progress to blastocyst in conditions of $\mathrm{pH}$ $\sim 8.2$ (normal embryo culture media $\mathrm{pH} \sim 7.3$ ), provided $\mathrm{HCO}_{3}^{-} / \mathrm{Cl}^{-}$exchange is functional (Zhao et al. 1995).

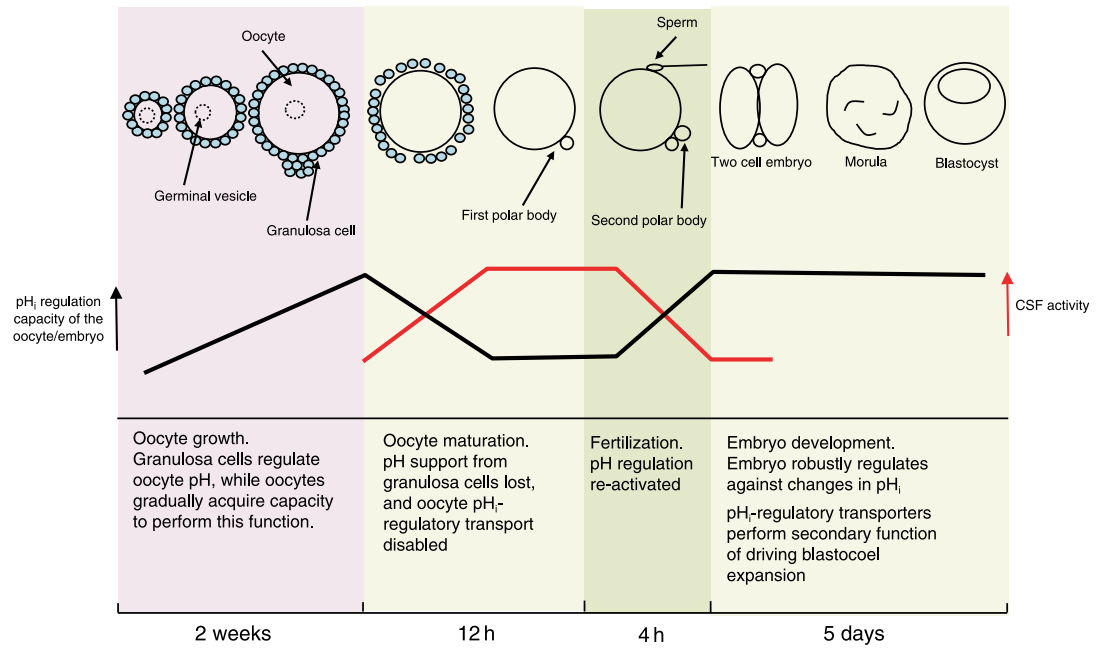

Figure 1 Regulation of intracellular $\mathrm{pH}$ changes in mammalian oogenesis and embryogenesis. Cartoon outlining the major milestones of oocyte development and early embryogenesis in mammals, indicating the relative level of $\mathrm{pH}$ regulation capacity displayed by the oocyte. Note that times indicated are for mouse, the most closely studied mammal in terms of $\mathrm{pH}_{\mathrm{i}}$ regulation. Granulosa cells are indicated in green, and the germinal vesicle as a dotted line. Further details are in text and in Table 1. 
PI mouse embryos also exhibit NHE activity for correcting acidosis (Gibb et al. 1997, Lane et al. 1998, Steeves et al. 2001, Harding et al. 2002). Oddly, NHE activity in mouse embryos varies widely among mouse strains, and in at least some strains it is not robust (Steeves et al. 2001). As is the case for $\mathrm{HCO}_{3}^{-} / \mathrm{Cl}^{-}$ exchanger activity, NHE activity is present in the PI embryos of human (Phillips et al. 2000), hamster (Lane et al. 1998), and bovine (Lane \& Bavister 1999), and inhibition impairs PI development (Lane et al. 1998). In addition, early embryos possess monocarboxylate transporters that cotransport $\mathrm{H}^{+}$and can influence $\mathrm{pH}_{\mathrm{i}}$ of the embryo (Harding et al. 1999), although this is not $\mathrm{pH}$ regulation per se, but a manifestation of passive transport of $\mathrm{H}^{+}$as lactic acid across the plasma membrane. In short, the mammalian PI embryo is well equipped with $\mathrm{pH}_{\mathrm{i}}$ regulation machinery that is essential for embryo development.

It is worth also noting that $\mathrm{pH}_{\mathrm{i}}$-regulatory exchangers perform a second role in embryos distinct from $\mathrm{pH}_{\mathrm{i}}$ regulation, which is to promote the formation of the blastocoel (embryo cavitation). Formation and expansion of the blastocoel are the result of an osmotic gradient driven by $\mathrm{Na}^{+}$accumulation within the cavity, which can be prevented by NHE inhibitors (Manejwala et al. 1989). Immunolocalization of NHE3 (SLC9A3) on the inner surface of the blastocoel (Barr et al. 1998) and inhibition of blastocoel formation using a NHE3selective inhibitor (Kawagishi et al. 2004) are very consistent with NHE3 playing the dominant role in blastocoel formation in mouse. In contrast, AE2 (SLC4A2)-mediated $\mathrm{HCO}_{3}^{-} / \mathrm{Cl}^{-}$exchange is necessary for $\mathrm{Cl}^{-}$efflux from the blastocoel (Zhao et al. 1997). The molecular identities (i.e. which isoforms) of the exchangers that regulate against $\mathrm{pH}$ changes during $\mathrm{PI}$ development are yet to be reported.

\section{$\mathrm{pH}$ regulation in the growing oocyte}

In stark contrast to embryos, a recent series of studies has revealed that ovarian oocytes that are growing and have yet to achieve their fully grown size lack the ability to regulate $\mathrm{pH}_{\mathrm{i}}$. These studies took advantage of the fact that, in mice, a wave of follicular development occurs shortly after birth such that oocyte size and follicular development are closely related to age during post-natal days 5-20. Thus, the ability of oocytes of different sizes to regulate their $\mathrm{pH}_{\mathrm{i}}$ could be examined. Small oocytes $(<\sim 50 \mu \mathrm{m}$ in diameter) that were isolated from the ovary and freed of granulosa cells (denuded) assumed a much lower 'resting' $\mathrm{pH}$ when placed in a standard culture medium than their fully grown $(70-75 \mu \mathrm{m}$ diameter) counterparts. Moreover, small oocytes apparently lacked both $\mathrm{HCO}_{3}^{-} / \mathrm{Cl}^{-}$and $\mathrm{Na}^{+} / \mathrm{H}^{+}$exchange activities, but these became increasingly active and capable of regulating $\mathrm{pH}_{\mathrm{i}}$ with increasing oocyte size. This activation of the transporters occurred mainly over the range $60-65 \mu \mathrm{m}$, mirroring the increase in resting $\mathrm{pH}$ within the oocyte, implying that the lower $\mathrm{pH}_{\mathrm{i}}$ of smaller oocytes was a result of inadequate $\mathrm{pH}_{\mathrm{i}}$ regulation (Erdogan et al. 2005).

Crucially, however, these initial experiments were unable to determine whether $\mathrm{pH}_{\mathrm{i}}$ of growing oocytes behaves similarly within the physiological environment of the ovarian follicle. Key to addressing this question were experiments in which the $\mathrm{pH}_{\mathrm{i}}$ of denuded and follicle-enclosed oocytes could be reliably and directly compared. This was achieved by microinjecting a $\mathrm{pH}$-sensitive fluorescent dye into both types of oocytes, allowing the $\mathrm{pH}_{\mathrm{i}}$ of the follicle-enclosed oocyte to be measured without any signal from the follicle cells (see Fig. 2A, for example). As in the previous study, small denuded oocytes adopted a much lower $\mathrm{pH}(\mathrm{pH} \sim 6.8)$, than fully grown denuded oocytes ( $\mathrm{pH} \sim 7.2)$. Strikingly, however, follicle-enclosed oocytes adopt essentially the same resting $\mathrm{pH}_{\mathrm{i}}$ regardless of their size $(\mathrm{pH}$ 7.2). Furthermore, fully grown denuded oocytes could efficiently recover from an experimentally induced acidosis or alkalosis, whereas in small oocytes normal $\mathrm{pH}_{\mathrm{i}}$ was only re-established when the oocyte was still enclosed within the follicle. Thus, granulosa cells provide the small growing oocyte with the ability to regulate against $\mathrm{pH}_{\mathrm{i}}$ changes, thereby allowing it to maintain a steady $\mathrm{pH}_{\mathrm{i}}$ during growth. This ability of the granulosa cells to 'assist' the oocyte in regulating its $\mathrm{pH}_{\mathrm{i}}$ is dependent upon gap junctions, since gap junction inhibition prevents small follicle-enclosed oocytes from dealing with induced $\mathrm{pH}$ changes, and causes the resting $\mathrm{pH}_{\mathrm{i}}$ to drop (FitzHarris \& Baltz 2006, FitzHarris et al. 2007).

Although these experiments reveal that granulosa cells are required to assist the oocyte in $\mathrm{pH}$ regulation, and that oocyte-granulosa gap junction communication is essential for this function, the mechanism of this assistance is somewhat more difficult to establish conclusively. One possibility is that oocyte-granulosa gap junctions allow the granulosa cells to pass to the oocyte a factor(s) that activates $\mathrm{pH}_{\mathrm{i}}$-regulatory mechanisms endogenous to the oocyte. Alternatively, gap junctions may allow the granulosa cells' direct access to the ooplasm, thereby allowing granulosa cells to regulate the $\mathrm{pH}_{\mathrm{i}}$ of the oocyte on its behalf. Although both possibilities are plausible, the available evidence is more consistent with a model in which $\mathrm{pH}$-regulatory transporters in the granulosa cells 'directly' regulate the $\mathrm{pH}$ of the oocyte through the gap junctions. Using techniques in which intact shells of granulosa shells are prepared from follicles, it was found that granulosa cells themselves possess robust and substantial $\mathrm{pH}$-regulatory mechanisms (FitzHarris \& Baltz 2006). These include $\mathrm{HCO}_{3}^{-} / \mathrm{Cl}^{-}$exchange for correcting alkalosis, $\mathrm{Na}^{+} / \mathrm{H}^{+}$ exchange for acidosis recovery provided by expression of two different NHE isoforms (NHE1 (SLC9A1) and NHE3), and a $\mathrm{Na}^{+}$-independent means of acidosis recovery which was identified as a V-ATPase, or proton pump 

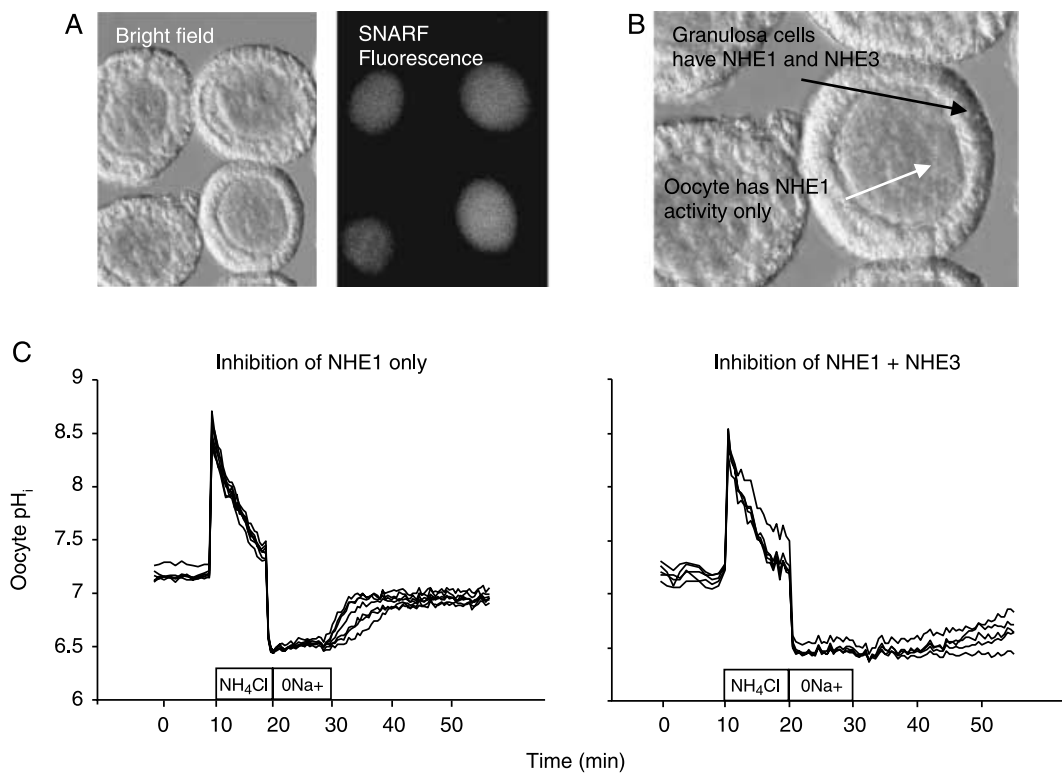

Figure 2 Follicle-enclosed oocytes recover from an induced acidosis unless $\mathrm{Na}^{+} / \mathrm{H}^{+}$exchanger isoforms 1 and 3 are simultaneously inhibited. (A) Example of follicle-enclosed oocytes isolated from the ovaries of 10-day-old mice and microinjected with the pH-sensitive fluorophore SNARFdextran $(10 \mathrm{kDa})$. Note that the $10 \mathrm{kDa}$ dextran prevents the indicator from diffusing through gap junctions, which permit the passage of molecules $<\sim 1 \mathrm{kDa}$, thereby allowing oocyte $\mathrm{pH}$ to be measured directly without any contaminating fluorescence from the granulosa cells. (B) Summary of known locations of active NHEs within murine follicles. (C) The ability of the oocyte to recover from acidosis is assessed using the $\mathrm{NH}_{4}$-pulse assay. The 10 min pulse of $\mathrm{NH}_{4} \mathrm{Cl}$ causes a net acidosis. Note that following re-addition of $\mathrm{Na}^{+}, \mathrm{pH}_{\mathrm{i}}$ recovers normally in the presence of $10 \mu \mathrm{M}$ cariporide, a concentration that inhibits all $\mathrm{Na}^{+} / \mathrm{H}^{+}$exchange attributable to NHE1 (SLC9A1). However, recovery from acidosis is completely

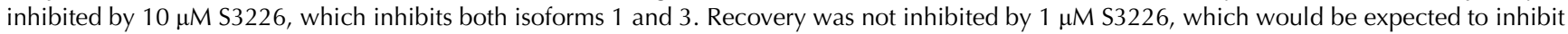
NHE3 (SLC9A3) but not NHE1 (not shown; see Schwark et al. 1998, Masereel et al. 2003 regarding selective NHE inhibitors). Thus, inhibition of NHE isoforms 1 and 3 is necessary to prevent recovery.

(FitzHarris et al. 2007). In each case, the transporter activities measured in the granulosa cells closely resembled those found in the follicle-enclosed oocyte. Most compellingly, the V-ATPase activity was never evident in denuded oocytes, regardless of size, but is easily detected in granulosa cell-enclosed oocytes. Thus, the array of $\mathrm{pH}_{\mathrm{i}}$ regulation mechanisms available to the small follicle-enclosed oocyte matches that of the follicle cells.

To further address the question, we have sought to exploit the different array of transporters in the two cell types. Granulosa cells express both NHE1 and NHE3, and simultaneous inhibition of both isoforms is necessary to suppress the ability of granulosa cells to recover from acidosis. Fully grown denuded oocytes, on the other hand, regulate against acidosis using $\mathrm{Na}^{+} / \mathrm{H}^{+}$exchange provided exclusively by NHE1 (see Table 1 ; FitzHarris et al. 2007). We reasoned that if regulation against oocyte acidosis in small follicle-enclosed oocytes is performed by $\mathrm{Na}^{+} / \mathrm{H}^{+}$exchange within the granulosa cells, then inhibition of both NHE1 and NHE3 should be necessary to prevent acidosis recovery in follicle-enclosed oocytes. Conversely, if granulosa cells activate $\mathrm{Na}^{+} / \mathrm{H}^{+}$exchange native to the oocyte, then inhibition of NHE1 alone should be sufficient to prevent acid correction in small follicle-enclosed oocytes. The results of these experiments are shown in Fig. 2C. Oocytes within follicles exposed to high concentrations of cariporide, a NHE1-specific inhibitor, recover from an induced acidosis as normal, whereas simultaneous inhibition of NHE1 and NHE3 using relatively high concentrations of S3226 prevents oocyte recovery in the follicle, implying that $\mathrm{pH}_{\mathrm{i}}$ regulation in the granulosa cells has to be inhibited to prevent $\mathrm{pH}_{\mathrm{i}}$ regulation in the follicleenclosed oocyte. Although the possibility that granulosa cells provide a signal to the growing oocyte that activates $\mathrm{Na}^{+} / \mathrm{H}^{+}$exchange other than NHE1 cannot be formally ruled out, this seems unlikely given that the fully grown oocyte utilizes only NHE1. Thus, we strongly favour a model in which the small growing oocyte, which is incapable of regulating its own $\mathrm{pH}$, has instead 'outsourced' this function to the granulosa cells.

The growing oocyte thus provides the first clear example of a mammalian cell that is incapable of regulating its $\mathrm{pH}_{\mathrm{i}}$ by conventional means until the oocyte reaches such a size that its own $\mathrm{pH}_{\mathrm{i}}$-regulatory transport is activated. The mechanism by which this transport activity is eventually activated in the oocyte remains to be established. Since a wave of new protein synthesis accompanies oocyte growth (Schultz \& Wassarman 1977), it is easy to imagine that the activation of transport represents the first time when the transporters reside in the plasma membrane at sufficient abundance to affect cytosolic $\mathrm{pH}$. Accordingly, the granulosa cells have highly developed $\mathrm{pH}$ regulation mechanisms, 
Table 1 Summary of $\mathrm{pH}$ regulation during oogenesis and embryogenesis in mammals.

\begin{tabular}{|c|c|c|c|c|c|}
\hline & Granulosa cells & $\begin{array}{l}\text { Growing and fully } \\
\text { grown GV oocyte }\end{array}$ & Unfertilized egg & Early preimplantation embryo & Late preimplantation embryo \\
\hline \multirow[t]{4}{*}{ Acidosis correction } & $\begin{array}{l}\mathrm{Na}^{+} / \mathrm{H}^{+} \text {exchange by } \\
\mathrm{NHE} 1,3 \text { V-type } \\
\mathrm{H}^{+} \text {-ATPase activity } \\
\text { (FitzHarris et al. } 2007 \text { ) }\end{array}$ & $\begin{array}{l}\mathrm{Na}^{+} / \mathrm{H}^{+} \text {gradually } \\
\text { activated during growth: } \\
\mathrm{NHE1} \text { responsible } \\
\text { (FitzHarris } \text { et al. 2007) }\end{array}$ & $\begin{array}{l}\text { Little or no transport activities } \\
\text { detected (G FitzHarris \& } \\
\text { JM Baltz, unpublished data; } \\
\text { Lane \& Bavister 1999, } \\
\text { Lane et al. 1999a, } \\
\text { Phillips \& Baltz 1999, } \\
\text { Phillips et al. 2002) }\end{array}$ & $\begin{array}{l}\mathrm{Na}^{+} / \mathrm{H}^{+} \text {exchange } \\
\text { active - possibly NHE1 } \\
\text { and } 3 \text { (Lane et al. 1998, } \\
\text { Phillips et al. 2000, } \\
\text { Harding et al. 2002) }\end{array}$ & $\begin{array}{l}\text { NHE3 participates in } \\
\text { blastocoel expansion } \\
\text { (Kawagishi et al. 2004) }\end{array}$ \\
\hline & $\begin{array}{l}\text { Possible NBC activity } \\
\quad \text { (FitzHarris et al. 2007) }\end{array}$ & $\begin{array}{l}\text { Transcripts for NHE1 and } \\
3 \text { detected (FitzHarris } \\
\text { et al. 2007) }\end{array}$ & $\begin{array}{l}\text { Transcripts for NHE1, } \\
3 \text { and } 4 \text { detected (G FitzHarris } \\
\text { \& JM Baltz, unpublished data; } \\
\text { Harding et al. 2002) }\end{array}$ & $\begin{array}{l}\text { MCT1 active two-cell stage } \\
\text { onwards (Gibb et al. 1997, } \\
\text { Harding et al. 1999) }\end{array}$ & $\begin{array}{l}\mathrm{Na}^{+} / \mathrm{H}^{+} \text {exchange active: } \\
\text { possibly by NHE1, 3, } 4 \text { (Lane } \\
\text { et al. 1998, Harding } \\
\text { et al. 2002) }\end{array}$ \\
\hline & $\begin{array}{l}\text { Transcripts for NHE1+3 } \\
\text { detected (FitzHarris } \\
\text { et al. 2007) }\end{array}$ & & & $\begin{array}{l}\text { NHE1 and } 3 \text { transcripts detected } \\
\quad \text { (Barr et al. 1998) }\end{array}$ & $\begin{array}{l}\text { NHE1 and NHE3 protein } \\
\text { at apical and basolateral } \\
\text { membrane respectively }\end{array}$ \\
\hline & & & & $\begin{array}{l}\text { MCT1, 2, } 3 \text { transcripts detected } \\
\text { two-cell onwards (Harding } \\
\text { et al. 1999) }\end{array}$ & $\begin{array}{l}\text { NHE1 transcripts, but not } \\
\text { NHE3 (Barr et al. 1998) }\end{array}$ \\
\hline \multirow[t]{3}{*}{ Alkalosis correction } & $\begin{array}{l}\mathrm{HCO}_{3}^{-} / \mathrm{Cl}^{-} \text {exchange active, } \\
\text { isoform unknown } \\
\text { (FitzHarris \& Baltz 2006) }\end{array}$ & $\begin{array}{l}\mathrm{HCO}_{3}^{-} / \mathrm{Cl}^{-} \text {exchange gradually } \\
\text { activated during growth, } \\
\text { isoform unknown (Erdogan } \\
\text { et al. 2005, FitzHarris \& Baltz } \\
\text { 2006) }\end{array}$ & $\begin{array}{l}\text { No transport activities detected } \\
\text { (Phillips \& Baltz 1999; Lane } \\
\text { et al. 1999b) }\end{array}$ & $\begin{array}{l}\mathrm{HCO}_{3}^{-} / \mathrm{Cl}^{-} \text {exchange active, } \\
\text { isoform unknown (Baltz et al. } \\
\text { 1991, Zhao et al. 1995, } \\
\text { Phillips et al. 2000) }\end{array}$ & $\begin{array}{l}\mathrm{pH} \text {-regulatory } \mathrm{HCO}_{3}^{-} / \mathrm{Cl}^{-} \\
\text {exchange active, isoforms } \\
\text { unknown (Zhao et al. 1995) }\end{array}$ \\
\hline & & & $\begin{array}{l}\text { AE2 transcripts detected } \\
\quad \text { (Phillips \& Baltz 1999) }\end{array}$ & $\begin{array}{l}\text { AE2 protein in one-cell } \\
\text { embryos (JM Baltz \& SL Alper, } \\
\text { unpublished data) and four- to } \\
\text { eight- cell embryos (Zhao } \\
\text { et al. 1995) }\end{array}$ & $\begin{array}{l}\text { AE2 immunolocalizes to } \\
\text { basolateral memebrane and } \\
\text { involved in } \mathrm{Cl}^{-} \text {efflux during } \\
\text { blastocoel formation (Zhao } \\
\text { et al. 1997) }\end{array}$ \\
\hline & & & & $\begin{array}{l}\text { Transcripts and protein for } \\
\text { AE2 one cell onwards, } \\
\text { and AE3 two cell onwards } \\
\text { (Zhao et al. 1995) }\end{array}$ & $\begin{array}{l}\text { Transcripts and protein for } \\
\text { AE2 and AE3 (Zhao } \\
\text { et al. 1995) }\end{array}$ \\
\hline
\end{tabular}

Italics indicate expression data, whereas standard type refers to functional experiments. Note that the majority of work has been carried out on mouse and hamster, but the table also includes data from cow and human. Omission of an exchanger type does not indicate its absence at that developmental stage, rather the absence of available data. NHE1 also known as SLC9A1; NHE3 also known as SLC9A3; AE2 also known as SLC4A2; AE3 also known as SLC4A3. 
which, via gap junctions, regulate the ooplasm against $\mathrm{pH}$ change until the oocyte is capable of performing this function alone. Although it has previously been demonstrated that protons or proton equivalents can diffuse through gap junctions in cardiomyocytes (Swietach et al. 2003, Zaniboni et al. 2003), the mammalian follicle provides the first demonstration of gap junctions allowing one cell to be entirely responsible for regulating the $\mathrm{pH}_{\mathrm{i}}$ of its neighbour in a physiologically relevant setting. A clean and conclusive experiment demonstrating the developmental importance of $\mathrm{pH}_{\mathrm{i}}$ cooperativity in oocyte growth is yet to be presented and, indeed, difficult to conceive. Nonetheless, given the well-established effect of $\mathrm{pH}_{\mathrm{i}}$ perturbations on cellular function, it is hard to imagine that oocyte growth and development would be unaffected at $\sim 0.5 \mathrm{pH}$ units less than normal. It is noteworthy that since all other cell types including early embryos (Lane et al. 1999a, 1999b, Steeves et al. 2001, Harding et al. 2002) possess these mechanisms, a developmental switch must occur that inactivates $\mathrm{pH}$ regulation specifically within the female germ cell, the timing and mechanism of which are as yet unknown.

That granulosa cells provide physiological support for the growing oocyte is not without precedent. It has long been known that metabolic cooperativity between oocyte and granulosa cells underpins oocyte energy production. Although oocytes utilize glucose poorly, granulosa cells readily metabolize glucose and supply the oocyte with substrates that it can use (Biggers et al. 1967). The granulosa cells also facilitate uptake of some amino acids and nucleotides, which are ineffectively taken up by denuded oocytes, an effect dependent upon gap junctions (Cross \& Brinster 1974, Heller \& Schultz 1980, Colonna \& Mangia 1983, Haghighat \& Van Winkle 1990, Su et al. 2009). Recent work has shown that in the case of some amino acids, granulosa cells can respond to the increased demands of the oocyte by upregulating transporters in order to provide the oocyte with more substrate (Eppig et al. 2005). $\mathrm{pH}_{\mathrm{i}}$ regulation distinguishes itself from these mechanisms insofar as granulosa cells provide rapid homeostatic support to the oocyte in the form of an acute (seconds to minutes) response to $\mathrm{pH}_{\mathrm{i}}$ change using pre-existing transporters. It remains to be seen whether granulosa cells also take up the slack on behalf of the oocyte in terms of other aspects of ionic homeostasis, although a similar phenomenon has been noted for $\mathrm{Na}^{+} / \mathrm{Ca}^{+}$exchange in immature Xenopus laevis oocytes (Supplisson et al. 1991).

\section{$\mathrm{pH}$ regulation mechanisms during oocyte maturation and fertilization}

As outlined above, by the time it is fully grown, the GV stage mouse oocyte has developed robust mechanisms for regulating its own $\mathrm{pH}_{\mathrm{i}}$ (Erdogan et al. 2005, FitzHarris
\& Baltz 2006, FitzHarris et al. 2007). Similarly, the PI embryo from the pronuclear one-cell stage onwards exhibits robust ability to regulate its own $\mathrm{pH}_{\mathrm{i}}$ (see above). Thus, given that developmental stages occurring both before and after are each capable of regulating $\mathrm{pH}_{\mathrm{i}}$, it was surprising that the ovulated MII oocyte exhibits little or no ability to regulate its $\mathrm{pH}_{\mathrm{i}}$.

MII mouse oocytes lack both $\mathrm{HCO}_{3}^{-} / \mathrm{Cl}^{-}$exchanger activity and the ability to recover from experimentally induced alkalosis (Phillips \& Baltz 1999). A similar lack of $\mathrm{HCO}_{3}^{-} / \mathrm{Cl}^{-}$exchange activity has been shown in MII hamster oocytes (Lane et al. 1999a). The lack of $\mathrm{HCO}_{3}^{-} /$ $\mathrm{Cl}^{-}$exchange activity in mature unfertilized eggs may not be a property of all mammals, however, as human MII eggs are able to recover from alkalosis, and recovery is inhibited by DIDS (Dale et al. 1998, Phillips et al. 2000).

Similar to $\mathrm{HCO}_{3}^{-} / \mathrm{Cl}^{-}$exchange, there is no detectable NHE activity in the MIl oocytes of hamster (Lane et al. 1999b) or mouse (G FitzHarris, C Zhou \& JM Baltz, unpublished data). Unlike for $\mathrm{HCO}_{3}^{-} / \mathrm{Cl}^{-}$exchange, human MII oocytes also lack NHE activity as well, and only exhibit this activity in embryos after fertilization, similar to mouse and hamster (Phillips et al. 2000). Therefore, somewhat unexpectedly, the robust $\mathrm{pH}_{\mathrm{i}^{-}}$ regulatory capacity, which is developed during oocyte growth and evident in the fully-grown GV oocyte, is downregulated during meiotic maturation, and then reactivated following fertilization.

The most in-depth investigations of this phenomenon have been carried out on the $\mathrm{HCO}_{3}^{-} / \mathrm{Cl}^{-}$exchanger in the mouse. $\mathrm{HCO}_{3}^{-} / \mathrm{Cl}^{-}$exchange activity and the ability to regulate $\mathrm{pH}_{\mathrm{i}}$ against alkalosis begin to decrease after release from first meiotic prophase arrest, and decrease slowly during $\mathrm{MI}$ until exchanger activity becomes almost undetectable by the MI/MII transition (Phillips et al. 2002) and is undetectable in the arrested MII egg. However, after egg activation either by fertilization or experimentally induced parthenogenetic activation, $\mathrm{HCO}_{3}^{-} / \mathrm{Cl}^{-}$exchanger activity begins to reappear about $2-3 \mathrm{~h}$ post-egg activation and reaches a maximal level several hours later, when the zygotic pronuclei appear (Phillips \& Baltz 1999, Phillips et al. 2002, Cetinkaya \& Erdogan 2008). A similar time course of activation of NHE activity after egg activation has been seen in the hamster egg (Lane et al. 1999b). Thus, $\mathrm{pH}_{\mathrm{i}}$ regulation is 'turned off' during meiotic maturation and is quiescent in the ovulated MII egg. It is then reactivated following fertilization, remaining present throughout subsequent PI embryogenesis.

Since $\mathrm{pH}_{\mathrm{i}}$ regulation varies so dramatically during meiotic maturation, subsequent studies have focussed on the question of whether the same mechanisms that control meiotic progression and release from meiotic arrests may also participate in silencing the $\mathrm{pH}_{\mathrm{i}}$ regulation machinery. GV arrest is mediated by high CAMP maintained by an activated G-protein-coupled receptor (Mehlmann et al. 2004). Thus, GV oocytes have 
high cAMP levels, which then decrease to allow meiotic resumption. However, raising CAMP levels in oocytes after meiotic resumption did not reactivate $\mathrm{HCO}_{3}^{-} / \mathrm{Cl}^{-}$ exchange in MIl eggs, indicating that high cAMP was not sufficient to maintain $\mathrm{pH}_{\mathrm{i}}$-regulatory activity (Phillips et al. 2002). Similarly, the intracellular $\mathrm{Ca}^{2+}$ oscillations that follow fertilization to trigger the release of the MII arrest are not required for reactivation of $\mathrm{HCO}_{3}^{-} / \mathrm{Cl}^{-}$ exchange (Phillips et al. 2002). Reactivation is also independent of protein synthesis (Phillips \& Baltz 1999).

MII arrest is maintained by cytostatic factor (CSF), a cytoplasmic signal that is due, at least in part, to the MOS/MEK/MAPK pathway, (Colledge et al. 1994, Hashimoto et al. 1994). The temporal variation of MAPK activity during meiotic maturation inversely parallels the activity of $\mathrm{pH}_{\mathrm{i}}$-regulatory mechanisms described above. Manipulations that induce ectopically high MAPK activity in GV oocytes or maintain high levels in activated eggs (Moos et al. 1995) reveal that high MAPK activity is not compatible with the activity of $\mathrm{HCO}_{3}^{-} / \mathrm{Cl}^{-}$exchange in mouse oocytes (Phillips et al. 2002). Conversely, inhibiting MAPK activity using the specific MEK inhibitor U0126 in MI oocytes activated the normally quiescent $\mathrm{HCO}_{3}^{-} / \mathrm{Cl}^{-}$exchanger (Phillips et al. 2002). Unpublished experiments in which a constitutively activated form of MEK (Moos et al. 1996) was expressed in parthenogenetically activated eggs to more specifically maintain high MAPK activity after egg activation has shown that maintaining high MAPK activity prevented reappearance of $\mathrm{HCO}_{3}^{-} / \mathrm{Cl}^{-}$ exchange, confirming a role for MEK and MAPK (C Zhou \& JM Baltz, unpublished data). Thus, the MAPK cascade that is necessary for CSF activity appears to have a novel role in controlling $\mathrm{pH}_{\mathrm{i}}$-regulatory mechanisms during meiosis.

Several questions remain to be answered. For example, what is the mechanism by which MAPK signalling inactivates the transporters during oocyte maturation? Although, in other cells, NHE1 is known to be regulated by MAPK via its effector P90rsk, MAPK activity normally activates $\mathrm{Na}^{+} / \mathrm{H}^{+}$exchange, rather than inactivating it (Orlowski \& Grinstein 2004), and little is known about the effect of MAPK signalling on $\mathrm{HCO}_{3}^{-} / \mathrm{Cl}^{-}$exchangers. Alternatively, perhaps MAPK triggers a process of transporter internalization and/or degradation during oocyte maturation, which is reversed following fertilization. Thus, the mechanism by which CSF inactivates transport in eggs requires further study. In addition, the physiological benefit of inactivating $\mathrm{pH}$ regulation in the unfertilized egg is obscure. One plausible possibility relates to the repetitive pulsatile increases in $\left[\mathrm{Ca}^{2+}\right]_{i}$, which occur after fertilization to trigger development. The re-activation of $\mathrm{pH}_{\mathrm{i}}$ regulation (when MAPK activity decreases) corresponds well with the cessation of $\mathrm{Ca}^{2+}$ oscillations (Jones et al. 1995, Marangos et al. 2003). Some pH-regulatory transporters are sensitive to $\mathrm{Ca}^{2+}$ or its downstream pathways, and thus inactivation of $\mathrm{pH}_{\mathrm{i}}$-regulatory transporters may prevent $\mathrm{Ca}^{2+}$-triggered $\mathrm{pH}_{\mathrm{i}}$ fluctuations following fertilization. Another possibility relates to cell volume regulation. In many cells, functionally coupled $\mathrm{Na}^{+} / \mathrm{H}^{+}$and $\mathrm{HCO}_{3}^{-} / \mathrm{Cl}^{-}$exchangers act to protect cells against unwanted shrinkage by importing $\mathrm{NaCl}$ to increase intracellular osmotic pressure (Jiang et al. 1997, Hoffman et al. 2009). Early embryos possess a novel mechanism for regulating their cell volume that relies on accumulation of glycine rather than inorganic ions (Steeves et al. 2003). This mechanism becomes activated during meiotic maturation (Tartia et al. 2009), i.e. during the period when $\mathrm{Na}^{+} / \mathrm{H}^{+}$and $\mathrm{HCO}_{3}^{-} / \mathrm{Cl}^{-}$exchanger is inactivated. Thus, it is possible that the inactivation of $\mathrm{pH}_{\mathrm{i}}$-regulatory mechanisms during meiosis occurs to allow the switch to glycine-based control in embryos. These possibilities remain to be investigated.

\section{Conclusion}

In summary (Fig. 1 and Table 1), the small growing oocyte lacks the ability to regulate $\mathrm{pH}_{\mathrm{i}}$, and therefore has to rely upon the surrounding granulosa cells. Paradoxically, the fully grown oocyte apparently has the machinery necessary to regulate its own $\mathrm{pH}$, but specifically inactivates this at the same time as it uncouples itself from the granulosa cells that were previously providing support (gap junction inactivation and cumulus expansion). Only after fertilization are these transporters re-activated. A summary of the transport mechanisms that have been identified so far as active in mammalian oocytes and embryos is presented in Table 1 . The challenge now is to understand the precise mechanisms that control the inactivation and reactivation of $\mathrm{pH}_{\mathrm{i}}$-regulatory mechanisms, and to ascertain how the changing $\mathrm{pH}$ of the external environment (follicle, oviduct, and uterus) and the changes in the manner in which the oocyte/embryo handles acid and alkali together impact $\mathrm{pH}_{\mathrm{i}}$ to affect the metabolism of the oocyte and embryo throughout PI development. Improved in vitro oocyte growth and maturation remain an important hurdle in the clinic, and understanding the interaction between the oocyte and its environment during these developmental milestones will likely be key in the development of improved culture systems.

\section{Declaration of interest}

There is no conflict of interest that could be perceived as prejudicing the impartiality of the research/work reported.

\section{Funding}

Work by the authors has been supported by the Canadian Institutes of Health Research in the form of a programme grant to J M Baltz and a fellowship to G FitzHarris. 


\section{References}

Alper SL 1991 The band 3-related anion exchanger (AE) gene family. Annual Review of Physiology 53 549-564.

Baltz JM, Biggers JD \& Lechene C 1991 Relief from alkaline load in two-cell stage mouse embryos by bicarbonate/chloride exchange. Journal of Biological Chemistry 266 17212-17217.

Barr KJ, Garrill A, Jones DH, Orlowski J \& Kidder GM 1998 Contributions of $\mathrm{Na}^{+} / \mathrm{H}^{+}$exchanger isoforms to preimplantation development of the mouse. Molecular Reproduction and Development 50 146-153.

Biggers JD, Whittingham DG \& Donahue RP 1967 The pattern of energy metabolism in the mouse oöcyte and zygote. PNAS $\mathbf{5 8}$ 560-567.

Buccione R, Schroeder AC \& Eppig JJ 1990 Interactions between somatic cells and germ cells throughout mammalian oogenesis. Biology of Reproduction 43 543-547.

Cetinkaya A \& Erdogan S 2008 Changes of $\mathrm{HCO}_{3}^{-} / \mathrm{Cl}^{-}$exchanger activity during meiotic maturation in Balb/c strain mouse oocytes and zygotes. Journal of Reproduction and Development 54 492-495.

Colledge WH, Carlton MB, Udy GB \& Evans MJ 1994 Disruption of c-mos causes parthenogenetic development of unfertilized mouse eggs. Nature 370 65-68.

Colonna R \& Mangia F 1983 Mechanisms of amino acid uptake in cumulus-enclosed mouse oocytes. Biology of Reproduction 28 797-803.

Cross PC \& Brinster RL 1974 Leucine uptake and incorporation at three stages of mouse oocyte maturation. Experimental Cell Research 86 $43-46$.

Dale B, Menezo Y, Cohen J, DiMatteo L \& Wilding M 1998 Intracellular pH regulation in the human oocyte. Human Reproduction 13 964-970.

Eppig JJ 1982 The relationship between cumulus cell-oocyte coupling, oocyte meiotic maturation, and cumulus expansion. Developmental Biology 89 268-272.

Eppig JJ 1985 Oocyte-somatic cell interactions during oocyte growth and maturation in the mammal. Developmental Biology 1 313-347.

Eppig JJ 1991 Intercommunication between mammalian oocytes and companion somatic cells. BioEssays 13 569-574.

Eppig JJ, Pendola FL, Wigglesworth K \& Pendola JK 2005 Mouse oocytes regulate metabolic cooperativity between granulosa cells and oocytes: amino acid transport. Biology of Reproduction 73 351-357.

Erdogan S, FitzHarris G, Tartia AP \& Baltz JM 2005 Mechanisms regulating intracellular $\mathrm{pH}$ are activated during growth of the mouse oocyte coincident with acquisition of meiotic competence. Developmental Biology 286 352-360.

FitzHarris G \& Baltz JM 2006 Granulosa cells regulate intracellular pH of the murine growing oocyte via gap junctions: development of independent homeostasis during oocyte growth. Development 133 591-599.

FitzHarris G, Siyanov V \& Baltz JM 2007 Granulosa cells regulate oocyte intracellular $\mathrm{pH}$ against acidosis in preantral follicles by multiple mechanisms. Development 134 4283-4295.

Gibb CA, Poronnik P, Day ML \& Cook DI 1997 Control of cytosolic pH in two-cell mouse embryos: roles of $\mathrm{H}(+)$-lactate cotransport and $\mathrm{Na}^{+} / \mathrm{H}^{+}$ exchange. American Journal of Physiology 273 C404-C419.

Grinstein S, Rotin D \& Mason MJ $1989 \mathrm{Na}^{+} / \mathrm{H}^{+}$exchange and growth factor-induced cytosolic $\mathrm{pH}$ changes. Role in cellular proliferation. Biochimica et Biophysica Acta 988 73-97.

Haghighat N \& Van Winkle LJ 1990 Developmental change in follicular cell-enhanced amino acid uptake into mouse oocytes that depends on intact gap junctions and transport system Gly. Journal of Experimental Zoology 253 71-82.

Harding EA, Day ML, Gibb CA, Johnson MH \& Cook DI 1999 The activity of the $\mathrm{H}^{+}$-monocarboxylate cotransporter during pre-implantation development in the mouse. Pflügers Archiv 438 397-404.

Harding EA, Gibb CA, Johnson MH, Cook DI \& Day ML 2002 Developmental changes in the management of acid loads during preimplantation mouse development. Biology of Reproduction $\mathbf{6 7}$ 1419-1429.

Hashimoto N, Watanabe N, Furuta $Y$, Tamemoto H, Sagata N, Yokoyama M, Okazaki K, Nagayoshi M, Takeda N, Ikawa Y et al. 1994 Parthenogenetic activation of oocytes in c-mos-deficient mice. Nature 370 68-71.
Heller DT \& Schultz RM 1980 Ribonucleoside metabolism by mouse oocytes: metabolic cooperativity between the fully grown oocyte and cumulus cells. Journal of Experimental Zoology 214 355-364.

Hoffmann EK, Lambert IH \& Pedersen SF 2009 Physiology of cell volume regulation in vertebrates. Physiological Reviews 89 193-277.

Jiang L, Chernova MN \& Alper SL 1997 Secondary regulatory volume increase conferred on Xenopus oocytes by expression of AE2 anion exchanger. American Journal of Physiology 272 C191-C202.

Jones KT, Carroll J, Merriman JA, Whittingham DG \& Kono T 1995 Repetitive sperm-induced $\mathrm{Ca}^{2+}$ transients in mouse oocytes are cell cycle dependent. Development 121 3259-3266.

Kapus A, Grinstein S, Wasan S, Kandasamy R \& Orlowski J 1994 Functional characterization of three isoforms of the $\mathrm{Na}^{+} / \mathrm{H}^{+}$exchanger stably expressed in Chinese hamster ovary cells. ATP dependence, osmotic sensitivity, and role in cell proliferation. Journal of Biological Chemistry $26923544-23552$.

Kawagishi R, Tahara M, Sawada K, Morishige K, Sakata M, Tasaka K \& Murata $\mathbf{Y} 2004 \mathrm{Na}^{+} / \mathrm{H}^{+}$exchanger-3 is involved in mouse blastocyst formation. Journal of Experimental Zoology. Part A, Comparative Experimental Biology 301 767-775.

Kawasaki-Nishi S, Nishi T \& Forgac M 2003 Proton translocation driven by ATP hydrolysis in V-ATPases. FEBS Letters 545 76-85.

Kidder GM \& Mhawi AA 2002 Gap junctions and ovarian folliculogenesis. Reproduction 123 613-620.

Lane M \& Bavister BD 1999 Regulation of intracellular pH in bovine oocytes and cleavage stage embryos. Molecular Reproduction and Development 54 396-401.

Lane M, Baltz JM \& Bavister BD 1998 Regulation of intracellular pH in hamster preimplantation embryos by the sodium hydrogen $\left(\mathrm{Na}^{+} / \mathrm{H}^{+}\right)$ antiporter. Biology of Reproduction 59 1483-1490.

Lane M, Baltz JM \& Bavister BD 1999a Bicarbonate/chloride exchange regulates intracellular $\mathrm{pH}$ of embryos but not oocytes of the hamster. Biology of Reproduction 61 452-457.

Lane M, Baltz JM \& Bavister BD $1999 \mathrm{~b} \mathrm{Na} / / \mathrm{H}^{+}$antiporter activity in hamster embryos is activated during fertilization. Developmental Biology 208 244-252.

Manejwala FM, Cragoe EJ Jr \& Schultz RM 1989 Blastocoel expansion in the preimplantation mouse embryo: role of extracellular sodium and chloride and possible apical routes of their entry. Developmental Biology 133 210-220.

Marangos P, FitzHarris G \& Carroll J $2003 \mathrm{Ca}^{2+}$ oscillations at fertilization in mammals are regulated by the formation of pronuclei. Development 130 1461-1472.

Masereel B, Pochet L \& Laeckmann D 2003 An overview of inhibitors of $\mathrm{Na}(+) / \mathrm{H}(+)$ exchanger. European Journal of Medicinal Chemistry 38 547-554.

Mehlmann LM, Saeki Y, Tanaka S, Brennan TJ, Evsikov AV, Pendola FL, Knowles BB, Eppig JJ \& Jaffe LA 2004 The Gs-linked receptor GPR3 maintains meiotic arrest in mammalian oocytes. Science 306 1947-1950.

Merzendorfer H, Graf R, Huss M, Harvey WR \& Wieczorek H 1997 Regulation of proton-translocating V-ATPases. Journal of Experimental Biology 200 225-235.

Moos J, Visconti PE, Moore GD, Schultz RM \& Kopf GS 1995 Potential role of mitogen-activated protein kinase in pronuclear envelope assembly and disassembly following fertilization of mouse eggs. Biology of Reproduction 53 692-699.

Moos J, Xu Z, Schultz RM \& Kopf GS 1996 Regulation of nuclear envelope assembly/disassembly by MAP kinase. Developmental Biology 175 358-361.

Nelson N \& Harvey WR 1999 Vacuolar and plasma membrane protonadenosinetriphosphatases. Physiological Reviews 79 361-385.

Orlowski J \& Grinstein S 2004 Diversity of the mammalian sodium/proton exchanger SLC9 gene family. Pflügers Archiv 447 549-565.

Phillips KP \& Baltz JM 1999 Intracellular $\mathrm{pH}$ regulation by $\mathrm{HCO}_{3}^{-} / \mathrm{Cl}^{-}$ exchange is activated during early mouse zygote development. Developmental Biology 208 392-405.

Phillips KP, Leveille MC, Claman P \& Baltz JM 2000 Intracellular pH regulation in human preimplantation embryos. Human Reproduction $\mathbf{1 5}$ 896-904. 
Phillips KP, Petrunewich MA, Collins JL \& Baltz JM 2002 The intracellular $\mathrm{pH}$-regulatory $\mathrm{HCO}_{3}^{-} / \mathrm{Cl}^{-}$exchanger in the mouse oocyte is in activated during first meiotic metaphase and reactivated after egg activation via the MAP kinase pathway. Molecular Biology of the Cell 13 3800-3810.

Pouyssegur J, Sardet C, Franchi A, L'Allemain G \& Paris S 1984 A specific mutation abolishing $\mathrm{Na}^{+} / \mathrm{H}^{+}$antiport activity in hamster fibroblasts precludes growth at neutral and acidic pH. PNAS 81 4833-4837.

Romero MF, Fulton CM \& Boron WF 2004 The SLC4 family of $\mathrm{HCO}_{3}^{-}$ transporters. Pflügers Archiv 447 495-509.

Schultz RM \& Wassarman PM 1977 Biochemical studies of mammalian oogenesis: protein synthesis during oocyte growth and meiotic maturation in the mouse. Journal of Cell Science 24 167-194.

Schwark JR, Jansen HW, Lang HJ, Krick W, Burckhardt G \& Hropot M 1998 S3226, a novel inhibitor of $\mathrm{Na}^{+} / \mathrm{H}^{+}$exchanger subtype 3 in various cell types. Pflügers Archiv 436 797-800.

Simon AM, Goodenough DA, Li E \& Paul DL 1997 Female infertility in mice lacking connexin 37. Nature 385 525-529.

Sorensen RA \& Wassarman PM 1976 Relationship between growth and meiotic maturation of the mouse oocyte. Developmental Biology 50 531-536.

Steeves CL, Lane M, Bavister BD, Phillips KP \& Baltz JM 2001 Differences in intracellular $\mathrm{pH}$ regulation by $\mathrm{Na}(+) / \mathrm{H}(+)$ antiporter among two-cell mouse embryos derived from females of different strains. Biology of Reproduction 65 14-22.

Steeves CL, Hammer MA, Walker GB, Rae D, Stewart NA \& Baltz JM 2003 The glycine neurotransmitter transporter GLYT1 is an organic osmolyte transporter regulating cell volume in cleavage-stage embryos. PNAS 100 13982-13987.

Su YQ, Sugiura K \& Eppig J 2009 Mouse oocyte control of granulosa cell development and function: paracrine regulation of cumulus cell metabolism. Seminars in Reproductive Medicine 27 32-42.
Supplisson S, Kado RT \& Bergman C 1991 A possible Na/Ca exchange in the follicle cells of Xenopus oocyte. Developmental Biology 145 $231-240$.

Swietach P, Zaniboni M, Stewart AK, Rossini A, Spitzer KW \& VaughanJones RD 2003 Modelling intracellular $\mathrm{H}(+)$ ion diffusion. Progress in Biophysics and Molecular Biology 83 69-100.

Tartia AP, Rudraraju N, Richards T, Hammer MA, Talbot P \& Baltz JM 2009 Cell volume regulation is initiated in mouse oocytes after ovulation. Development 136 2247-2254.

Wassarman PM, Schultz RM, Letourneau GE, LaMarca MJ, Josefowicz WJ \& Bleil JD 1979 Meiotic maturation of mouse oocytes in vitro. Advances in Experimental Medicine and Biology 112 251-268.

Zaniboni M, Rossini A, Swietach P, Banger N, Spitzer KW \& VaughanJones RD 2003 Proton permeation through the myocardial gap junction. Circulation Research 93 726-735.

Zhao Y \& Baltz JM 1996 Bicarbonate/chloride exchange and intracellular $\mathrm{pH}$ throughout preimplantation mouse embryo development. American Journal of Physiology 271 C1512-C1520.

Zhao Y, Chauvet PJ, Alper SL \& Baltz JM 1995 Expression and function of bicarbonate/chloride exchangers in the preimplantation mouse embryo. Journal of Biological Chemistry $27024428-24434$.

Zhao Y, Doroshenko PA, Alper SL \& Baltz JM 1997 Routes of $\mathrm{Cl}^{-}$transport across the trophectoderm of the mouse blastocyst. Developmental Biology 189 148-160.

Received 25 March 2009

First decision 20 May 2009

Accepted 11 June 2009 